\title{
Effects of protein kinase inhibitors on pig oocyte maturation in vitro
}

\author{
T Jung *, C Lee, RM Moor \\ Institute of Animal Physiology and Genetics Research, Department of Molecular Embryology, \\ Babraham, Cambridge CB2 4AT, UK
}

(Received 18 June 1992; accepted 9 September 1992)

\begin{abstract}
Summary - Normal oocyte maturation depends on signal transmission between granulosa cells and the oocyte. We have analysed the effects of inhibiting (I) cyclic AMP-dependent protein kinase (protein kinase A, PK-A), (II) $\mathrm{Ca}^{2+} /$ phospholipid-dependent protein kinase (protein kinase C, PK-C) and (III) calmodulin (CaM) on pig oocyte maturation in vitro, protein synthesis and phosphorylation. The inhibition of PK-A using a specific inhibitor $\mathrm{H} 8$, decreased the maturation rate (rate of germinal vesicle breakdown, GVBD) of cumulus-enclosed pig oocytes in a dose-dependent manner by $\approx 12 \%$, reaching a plateau at $100 \mu \mathrm{M}$. The inhibition of PK-C with $\mathrm{H} 7$, an inhibitor with some side-effects on PK-A, decreased the maturation rate of cumulus-enclosed oocytes in a dose-dependent manner to a maximum of $20 \%$ at a concentration of $100 \mu \mathrm{M}$. The calmodulin antagonist W7 up to a concentration of $200 \mu \mathrm{M}$ had no effects on maturation of cumulus-enclosed pig oocytes. None of the inhibitors ( $\mathrm{H} 7, \mathrm{H} 8$ and W7) altered the patterns of protein synthesis of either pig oocytes and cumulus cells after maturation in vitro. Oocyte phosphoprotein patterns were, however, clearly changed by W7. Cumulus cell protein phosphorylation patterns were changed by all 3 agents. Since inhibition of cyclic AMP and $\mathrm{Ca}^{2+}$ phospholipid pathways by PK-A and PK-C blocking chemicals affected only a limited proportion of oocytes (12 and $20 \%$, respectively) and inhibition of $\mathrm{Ca}^{2+}$ binding to $\mathrm{CaM}$ was without effect on oocyte maturation, we conclude that these pathways modulate rather than regulate oocyte maturation in the pig.
\end{abstract}

pig / oocyte maturation / protein kinase C / cyclic AMP-dependent protein kinase / calmodulin

Résumé - Effets des inhibiteurs des protéines kinases sur la maturation des ovocytes de porc in vitro. La maturation normale de l'ovocyte dépend de la transmission de signaux entre les cellules de la granulosa et l'ovocyte. Nous avons étudié l'effet d'une inhibition

- de la protéine kinase $A M P_{c}$-dépendante (protéine kinase $A, P K-A$ ),

- de la protéine kinase $C a^{2+} /$ phospholipide-dépendante (protéine kinase $C, P K-C$ ), et

- de la calmoduline (CaM), sur la maturation, la synthèse protéique et la phosphorylation d'ovocytes de porc in vitro.

L'inhibition de la PK-A, par l'inhibiteur spécifique H8, diminuait le taux de maturation (taux d'éclatement de la vésicule germinale) des ovocytes entourés du cumulus avec une intensité proportionnelle à la dose, atteignant un maximum de $12 \%$ à une concentration en $\mathrm{H} 8$ de $100 \mu \mathrm{M}$. L'inhibition de la PK-C par H7, composé qui inhibe aussi partiellement la PK-A, diminuait le taux de maturation des ovocytes entourés du cumulus proportionnellement à la dose avec un maximum de $20 \%$ à une concentration en H7 de $100 \mu \mathrm{M}$. L'inhibiteur W7 de la calmoduline, jusqu'à une concentration de $200 \mu \mathrm{M}$, n'avait pas d'effet sur la maturation des ovocytes entourés de cumulus. Aucun des inhibiteurs utilisés $(H 7, H 8$ et

* Present address: Institute of Radiation Hygiene Section of Nuclear Biology, Ingdstaedter Landstrasse 1, D-8042 Neuherberg /Munich, Germany. 
W7) n'a modifié qualitativement la synthèse protéique des ovocytes ou des cellules du cumulus après maturation in vitro. La répartition des phosphoprotéines était cependant clairement modifiée par W7 dans les ovocytes et par les 3 agents chimiques dans les cellules du cumulus. Puisque linhibition des voies de l'AMP ${ }_{c}$ et du $\mathrm{Ca}^{2+} /$ phospholipide par les substances bloquant l'activité de la PK-A ou la PK-C affectait seulement une proportion limitée des ovocytes (respectivement 12 et $20 \%$ ), et que l'inhibition de la fixation du $\mathrm{Ca}^{2+}$ à la calmoduline était sans effet sur la maturation, nous concluons que ces voies modulent plutôt que régulent la maturation des ovocytes de porc in vitro.

porc / maturation des ovocytes / protéine kinase C / protéine kinase $A M P_{c}$ dépendante / calmoduline

\section{INTRODUCTION}

Oocytes are coupled to the surrounding granulosa cells throughout oogenesis by gap junctions. After growing to the full size, oocytes resume maturation after receiving the appropriate hormonal stimulus. The period of meiotic arrest during the growth phase and the subsequent resumption of meiosis during maturation appear to be mediated by factors from the cumulus cells which are transferred into the oocytes via cellular junctions. There are a substantial number of reports supporting the hypothesis that cyclic adenosine monophosphate (cyclic AMP) is involved in maintaining meiotic arrest in mouse, rat and amphibian oocytes (mouse: Cho et al, 1974; Bornslaeger et al, 1986a; rat: Magnusson and Hillensjö, 1977; Dekel and Beers, 1978; amphibia: reviewed by Maller, 1983). This is based on the finding that cyclic AMP derivatives, such as dibutyryl cyclic AMP (dbcAMP), and activators of adenylate cyclase, like forskolin and cholera toxin, or inhibitors of phosphodiesterase, like 3-isobutyl-1-methylxanthine, inhibit germinal vesicle breakdown (GVBD). The cyclic AMP-dependent protein kinase (PK-A) is involved in the inhibitory action of cyclic AMP (Bornslaeger et al, 1986a). The dbcAMP-induced meiotic arrest can be overcome by increasing intracellular $\mathrm{Ca}^{2+}$ levels by $\mathrm{Ca}^{2+}$-ionophore treatment (Paleos and Powers, 1981; Powers and Paleos, 1982). Metabolism and action of cal- cium ions in eukaryotic cells are regulated by the interaction with calmodulin (CaM). CaM antagonists inhibit oocyte maturation in the mouse (Bornslaeger et al, 1986b; Sato and Koite, 1987). Furthermore, oocyte maturation is inhibited by activators of the $\mathrm{Ca}^{2+} /$ phospholipid-dependent protein kinase (protein kinase $\mathrm{C}, \mathrm{PK}-\mathrm{C}$ ) (Urner and Schorderet-Slatkine, 1984; Bornslaeger et al, 1986b). From these reports it is obvious that at least 2 intracellular second messenger systems are involved in the onset of oocyte maturation. Intracellular mediators of these second messenger systems are protein kinases whose activities are in turn regulated by them.

Little is known about the importance of the above-mentioned second messengers during oocyte maturation in domestic species. Pig oocytes are able to synthesize their own cyclic AMP (Racowsky, 1985). However, inhibitory effects of dbcAMP on pig oocyte maturation have been described (Rice and McGauchey, 1981).

To learn more about the importance of different second messenger systems and their mediating protein kinases during pig oocyte maturation, we blocked the activity of PK-A and PK-C with inhibitors and prevented binding of $\mathrm{Ca}^{2+}$ to $\mathrm{CaM}$ with an antagonist. Naphthalene sulfonamides, eg W7 ( $N$-[6-aminohexyl]-5-chloro-1-naphthalene sulfonamide), are cell-permeable CaM antagonists (Hidaka et al, 1978). When the naphthalene ring of these sulfonamides is replaced by isoquinoline the resulting 
agents are no longer CaM antagonists, but rather compounds that directly suppress protein kinase activity. The isoquinoline sulfonamides $\mathrm{H} 7$ (1-[5-isoquinolinesulfonyl]-2methylpiperazine) and $\mathrm{H} 8$ ( $\mathrm{N}$-[2-(methylamino)ethyl]-5-isoquinoline sulfonamide) are specific PK-C and PK-A inhibitors (Hidaka et al, 1984). In the present study we inhibited PK-A, PK-C or CaM in cumulusenclosed pig oocytes and had them analyzed for their potential to undergo GVBD and synthesize and phosphorylate proteins.

\section{MATERIALS AND METHODS}

\section{Collection and culture of oocytes}

Pig ovaries were collected from a local slaughterhouse and transported to the laboratory in a thermo-container within $30 \mathrm{~min}$. To maximize oocyte numbers without decreasing oocyte quality, whole ovaries were dissected with a multi-razor blade dissection system. After washing, cumulusenclosed oocytes with a minimum diameter of $115 \mu \mathrm{m}$ were selected. For experiments with denuded oocytes selected cumulus-enclosed oocytes were mechanically denuded. Dissection, washing and selection was carried out in medium 199 supplemented with $5 \%$ fetal calf serum. After selection oocytes were matured in vitro in medium 199 supplemented with $10 \%$ fetal calf serum, $1 \mathrm{mg} / \mathrm{ml}$ glutamine, $0.7 \mathrm{mg} / \mathrm{ml} \mathrm{L}$-ascorbic acid, $0.35 \mathrm{mg} / \mathrm{ml}$ insulin, $0.3 \mathrm{lU} / \mathrm{ml} \mathrm{hFSH}$, and $0.3 \mathrm{lU} / \mathrm{ml}$ $\mathrm{hLH}$ using a gentle agitation system. The activities of PK-A, PK-C or CaM were inhibited by the addition of $\mathrm{H} 7, \mathrm{H} 8$ or $\mathrm{W} 7$ to final concentrations of $0,50,100,150$ or $200 \mu \mathrm{M}$.

\section{Radiolabelling of oocyte proteins}

In order to study protein synthesis, cumulus enclosed pig oocytes were incubated for $2 \mathrm{~h}$ in [ $\left.{ }^{35} \mathrm{~S}\right]$-methionine (Tran ${ }^{35} \mathrm{~S}$-label, spec act $>37$ $\mathrm{TBq} / \mathrm{mmol}, \mathrm{ICN}$ ) at an isotope concentration of $37 \mathrm{MBq} / \mathrm{ml}$ using phosphate-free Hepesbuffered M2 medium. Protein phosphorylation was studied by labelling oocytes for $2 \mathrm{~h}$ in $\left[{ }^{32} \mathrm{P}\right]$ - orthophosphate (carrier-free, ICN) at an isotope concentration of $37 \mathrm{MBq} / \mathrm{ml}$ using phosphatefree Hepes-buffered M2 medium. All labelled oocytes were denuded of cumulus cells before collection for electrophoresis. Labelling of the inhibitor treated oocytes was performed in the presence of $100 \mu \mathrm{M} \mathrm{H} 8, \mathrm{H} 7$ or $\mathrm{W} 7$, respectively.

\section{Assessment of oocyte maturation}

The effects of the inhibitors of PK-A, PK-C or $\mathrm{CaM}$ on in vitro maturation of cumulus-enclosed or denuded pig oocytes were determined by fixing whole oocytes in ethanol-acetic acid (3:1) and staining with orcein. All statistical comparisons were made by $\chi^{2}$-square tests.

\section{Gel electrophoresis}

Samples were collected in $2 \mu \mathrm{l}$ phosphate-buffered saline and lysed with $15 \mu \mathrm{l}$ of $2 x$-concentrated SDS-sample buffer and $2 \mu \mathrm{l}$ were removed for measuring the incorporation of label into TCAprecipitable material. One-dimensional electrophoresis was performed on $8-15 \%$ linear gradient SDS-polyacrylamide gels (Laemmli, 1969). Direct autoradiography was carried out on dried gels using Hyperfilm $\beta$-max (Amersham).

\section{RESULTS}

Pig oocytes dissected from ovaries and cultured in vitro undergo germinal vesicle breakdown after $\approx 24 \mathrm{~h}$. The metaphase I stage than persists for $\approx 8 \mathrm{~h}$. The timing of the maturation cycle of individual oocytes may, however, vary by $\approx 3-4 \mathrm{~h}$ from the median outlined above.

\section{Effects of the protein kinase inhibitor $H 8$ on GVBD}

Cumulus-enclosed pig oocytes were matured in vitro for $30 \mathrm{~h}$ in the presence of increasing concentrations of $\mathrm{H} 8$ (table 1). 
Table I. Effects of $\mathrm{H} 8$ on cumulus enclosed pig oocytes after $30 \mathrm{~h}$ in vitro.

\begin{tabular}{|c|c|c|c|c|c|c|c|c|c|c|}
\hline \multirow[b]{3}{*}{$\begin{array}{l}\text { Germinal vesicle stage } \\
\text { Metaphase I } \\
\text { Anaphase I/ telophase I } \\
\text { Metaphase II }\end{array}$} & \multirow{2}{*}{$\begin{array}{c}0 \\
44\end{array}$} & \multirow{2}{*}{$(22.9 \%)$} & \multirow{2}{*}{$\frac{50}{43}$} & \multirow{2}{*}{\multicolumn{3}{|c|}{$\begin{array}{c}H 8 \text { concentrations }(\mu M) \\
100^{2}\end{array}$}} & \multirow{2}{*}{$150^{a}$} & \multirow{2}{*}{\multicolumn{3}{|c|}{$200^{a}$}} \\
\hline & & & & & & & & & & \\
\hline & $\begin{array}{r}44 \\
139 \\
8 \\
1\end{array}$ & $\begin{array}{r}(22.9 \%) \\
(72.4 \%) \\
(4.2 \%) \\
(0.5 \%)\end{array}$ & $\begin{array}{r}43 \\
102 \\
1 \\
0\end{array}$ & $\begin{array}{r}(29.5 \%) \\
(69.9 \%) \\
(0.7 \%)\end{array}$ & $\begin{array}{c}72^{\mathrm{b}} \\
118^{\mathrm{c}} \\
4 \\
2\end{array}$ & $\begin{array}{r}(36.7 \%) \\
(60.2 \%) \\
(2.0 \%) \\
(1.0 \%)\end{array}$ & $\begin{array}{r}52^{b} \\
102 \\
4 \\
1\end{array}$ & $\begin{array}{r}(32.7 \%) \\
(64.2 \%) \\
(2.5 \%) \\
(0.6 \%)\end{array}$ & $\begin{array}{r}56^{b} \\
102 \\
2 \\
0\end{array}$ & $\begin{array}{r}(35.0 \%) \\
(63.8 \%) \\
(1.3 \%)\end{array}$ \\
\hline No of oocytes & 192 & & 146 & & 196 & & 159 & & 160 & \\
\hline
\end{tabular}

a The distributions of maturation stages after treatment with 100,150 , or $200 \mu \mathrm{M} \mathrm{H} 8$ show a statistically significant difference from $0 \mu \mathrm{M} \mathrm{H8}$ with probabilities of $P \leq 0.001$, or $P \leq 0.01$, or $P \leq 0.001$, respectively. ${ }^{b}$ The number of oocytes unable to mature (germinal vesicle stage) after treatment with 100,150 or $200 \mu \mathrm{M} \mathrm{H} 8$ are statistically significantiy higher compared to $0 \mu \mathrm{MH} H$ with probabilities of $P \leq 0.001, P \leq 0.005$, or $P \leq 0.001$, respectively. ${ }^{c}$ The number of oocytes reaching metaphase I stage after treatment with $100 \mu \mathrm{M} \mathrm{H} 8$ is statistically significantly lower compared to $0 \mu \mathrm{M} \mathrm{H} 8$ with a probability of $P \leq 0.01$.

Treatment of pig oocytes with $\mathrm{H} 8$ decreased the proportion of oocytes which induced GVBD in a dose-dependent manner from 0 to $100 \mu \mathrm{M}$, reaching a plateau with no further increase when higher concentrations were used. The plateau was $\approx 12 \%$ below control levels. The inhibitory effect of $\mathrm{H} 8$ was statistically significantly different between control and 100,150, or $200 \mu \mathrm{M}$ treatment groups (table I). There was no difference between the control and the $50 \mu-\mathrm{M}$ treatment group and between the individual treatments $(P>0.05)$.

Similar experiments were performed with denuded pig oocytes (data not shown). High concentrations of $\mathrm{H} 8$ (100 $\mu \mathrm{M}$ or over) did not affect oocyte maturation in vitro. However, there was a slight improvement of maturation in denuded pig oocytes with $50 \mu \mathrm{M} \mathrm{H8}$.

\section{Effects of the protein kinase inhibitor $H 7$ on GVBD}

$\mathrm{H} 7$ had a similar dose-dependent but a more pronounced inhibitory effect on the maturation of cumulus-enclosed pig oo- cytes after $30 \mathrm{~h}$ culture in vitro than was observed after $\mathrm{H} 8$ treatment (table II). Increasing concentrations of $\mathrm{H} 7$ decreased the proportion of oocytes able to mature in a dose-dependent manner from 0 to 100 $\mu \mathrm{M}$, reaching a plateau with no further increase when higher concentrations of the inhibitor were used. This plateau was $\approx 17-24 \%$ below control levels. The inhibitory effect of $\mathrm{H} 7$ was statistically significantly different between control oocytes and $\mathrm{H} 7$-treated oocytes $(100,150,200 \mu \mathrm{M}$, table II). There was no difference between the control and the $50 \mu \mathrm{M}$ group and between different treatments $(P>0.05)$.

In contrast to $\mathrm{H} 8$ however, $\mathrm{H} 7$ had a significant effect on the in vitro maturation of denuded pig oocytes (data not shown). The effect was similar to that on cumulusenclosed oocytes, with a plateau at 100 $\mu \mathrm{M}$ or at higher concentrations of $\mathrm{H} 7$.

\section{Effects of a combined treatment of $H 7$ and $H 8$ on GVBD}

Pig oocytes were treated with $50 \mu \mathrm{M} \mathrm{H7}$ and $50 \mu \mathrm{M} \mathrm{H} 8$ and the results compared 
Table II. Effects of $\mathrm{H} 7$ on cumulus enclosed pig oocytes after $30 \mathrm{~h}$ in vitro.

\begin{tabular}{|c|c|c|c|c|c|}
\hline & \multicolumn{5}{|c|}{$H 7$ concentrations $(\mu M)$} \\
\hline & 0 & 50 & $100^{a}$ & $150^{a}$ & $200^{a}$ \\
\hline Germinal vesicle stage & $46(26.1 \%)$ & $34(33.3 \%)$ & $42^{b}(43.3 \%)$ & $38 \mathrm{~b}(44.7 \%)$ & $49^{b}(50.0 \%)$ \\
\hline Metaphase I & $123(69.8 \%)$ & $65(63.7 \%)$ & $51^{c}(52.6 \%)$ & $46(54.1 \%)$ & $48^{\circ}(49.0 \%)$ \\
\hline Anaphase I/telophase I & $6(3.4 \%)$ & $3(2.9 \%)$ & $4(4.1 \%)$ & $1 \quad(1.2 \%)$ & $1(1.0 \%)$ \\
\hline Metaphase II & $1(0.6 \%)$ & 0 & 0 & 0 & 0 \\
\hline No of oocytes & 176 & 102 & 97 & 85 & 98 \\
\hline
\end{tabular}

a The distributions of maturation stages after treatment with 100,150 , or $200 \mu \mathrm{M} \mathrm{H} 8$ show a statistically significant difference from $0 \mu \mathrm{M} \mathrm{H} 8$ with probabilities of $P \leq 0.005$, or $P \leq 0.0005$, or $P \leq 0.001$, respectively. ${ }^{b}$ The number of oocytes unable to mature (germinal vesicle stage) after treatment with 100,150 or $200 \mu \mathrm{M} \mathrm{H7}$ are statistically significantly higher compared to $0 \mu \mathrm{M} \mathrm{H} 7$ with probabilities of $P \leq 0.001, P \leq 0.001$, or $P \leq 0.001$, respectively. ${ }^{\circ}$ The number of oocytes reaching metaphase I stage after treatment with 100 or $200 \mu \mathrm{M} \mathrm{H7}$ is statistically significantly lower compared to $0 \mu \mathrm{M} \mathrm{H} 7$ with probabilities of $P \leq 0.01$ or $P \leq 0.01$ respectively.

with the expected distribution calculated as a simple additive effect of the single treatments with $50 \mu \mathrm{M} \mathrm{H} 7$ and $50 \mu \mathrm{M} \mathrm{H8}$, respectively. The combined treatment of cumulus enclosed pig oocytes reduced the proportion of oocytes able to mature in vitro (table III). However, the observed distribution of maturation stages was not different from that expected, indicating simple additive effects between the treatments.

Table III. Effects of a combined treatment of $\mathrm{H} 7$ and $\mathrm{H} 8$ on cumulus enclosed pig oocytes after $30 \mathrm{~h}$ in vitro.

$$
\begin{aligned}
& H 7 \text { or } H 8 \text { concentration }(\mu M) \quad \text { Expected distribution }{ }^{\mathrm{e}} \\
& \mathrm{O}^{\mathrm{a}} \quad 50 \mathrm{H7}+50 \mathrm{H}^{\mathrm{b}}
\end{aligned}
$$

$\begin{array}{lccc}\text { Germinal vesicle stage } & 90(24.5 \%) & 52^{\mathrm{c}}(41.6 \%) & 48(38.2 \%) \\ \text { Metaphase I } & 262(71.2 \%) & 69^{\mathrm{d}}(55.2 \%) & 77^{\mathrm{f}}(61.8 \%) \\ \text { Anaphase I/ telophase I } & 14(3.8 \%) & 1(0.8 \%) & \\ \text { Metaphase II } & 2(0.5 \%) & 3(2.4 \%) & 125 \\ \text { No } & 368 & 125 & \end{array}$

a Sum of oocytes from groups $0 \mu \mathrm{M} \mathrm{H} 7$ (table II) and $0 \mu \mathrm{M} \mathrm{H8}$ (table I). ${ }^{\mathrm{b}}$ The distribution of maturation stages after a combined treatment of $50 \mu \mathrm{M} \mathrm{H} 7$ and $50 \mu \mathrm{M} \mathrm{H} 8$ shows a statistically significant difference from control oocytes $(0$ $\mu \mathrm{M}$ ) with a probability of $P \leq 0.001$. $^{\mathrm{c}}$ The number of oocytes unable to mature (germinal vesicle stage) after a combined treatment is statistically significantly higher compared to control oocytes with a probability of $P \leq 0.001$. $d$ The number of oocytes reaching metaphase I after a combined treatment is statistically significantly lower compared to control oocytes with a probability of $P \leq 0.01$, e The expected numbers of oocytes for the different maturation stages were calculated as an additive effect from the numbers given for the single treatments with $50 \mu \mathrm{m} \mathrm{H8}$ and $50 \mu \mathrm{m} \mathrm{H7}$ in tables I and II, respectively. There is no difference between observed and expected distribution. ${ }^{f}$ The number given stands for the sum of the maturation stages metaphase I, anaphase I/ telophase I and metaphase II. 


\section{Effects of the calmodulin antagonist W7 on GVBD}

Cumulus enclosed (table IV) and denuded (data not shown) pig oocytes treated with increasing concentrations of W7 $(50,100$, 150 and $200 \mu \mathrm{M})$ matured in vitro at rates comparable to control oocytes. There were no significant differences between groups.

\section{Protein synthesis and phosphorylation pattern of pig oocytes and cumulus cells after inhibitor treatment}

Cumulus-enclosed pig oocytes were matured in vitro in the presence of the protein kinase inhibitors $\mathrm{H} 7$ or $\mathrm{H} 8$ or the $\mathrm{CaM}$ antagonist W7. During the last $2 \mathrm{~h}$ of in vitro culture, the oocytes were labelled with [35S]-methionine or [32P]-orthophosphate to analyze protein synthesis or protein phosphorylation, respectively. After labelling, the oocytes were mechanically denuded and oocytes and cumulus cells were collected separately and analyzed by 1-dimensional electrophoresis and autoradiography.

After treatment of cumulus-enclosed oocytes with $\mathrm{H} 7, \mathrm{H} 8$ and $\mathrm{W} 7$ the levels of protein synthesis and phosphorylation in oocytes and cumulus cells were compara- ble with the controls, respectively (data not shown). The protein synthesis pattern of pig oocytes and cumulus cells after treatment with the inhibitors were indistinguishable from those of metaphase I stage oocytes and the control cumulus cells, respectively (fig 1 ).

Protein phosphorylation pattern of oocytes were not altered after $\mathrm{H} 7$ and $\mathrm{H} 8$ treatment. W7, however, inhibited the phosphorylation of a $200-\mathrm{kDa}$ protein in oocytes (fig 2). Cumulus cell phosphorylation was affected by all 3 inhibitors. $\mathrm{H} 8$ increased the phosphorylation of a $23-\mathrm{kDa}$ protein. $\mathrm{H} 7$ decreased phosphorylation of 33 and $28 \mathrm{kDa}$ bands. Phosphorylation of the $28 \mathrm{kDa}$ protein was also inhibited by W7 (fig 2).

\section{DISCUSSION}

We report on the effects of isoquinoline sulfonamides $\mathrm{H} 7$ and $\mathrm{H} 8$ as inhibitors of cyclic AMP-dependent protein kinase (PKA) and $\mathrm{Ca}^{2+} /$ phospholipid-dependent protein kinase (protein kinase C, PK-C) and of the naphthalene sulfonamide $W 7$ as an antagonist of calmodulin (CaM) on pig oocyte maturation in vitro. Our work was based on the hypothesis that by using these cellpermeable substances we would be able to discriminate between the roles which

Table IV. Effects of W7 on cumulus enclosed pig oocytes after $30 \mathrm{~h}$ in vitro.

\begin{tabular}{|c|c|c|c|c|c|}
\hline & \multicolumn{5}{|c|}{$W 7$ concentration $(\mu M)$} \\
\hline & 0 & 50 & 100 & 150 & 200 \\
\hline Germinal vesicle stage & $22(22.4 \%)$ & $26(27.1 \%)$ & $25(29.1 \%)$ & $26(28.0 \%)$ & $18(20.7 \%)$ \\
\hline Metaphase I & $69(70.4 \%)$ & $66(68.8 \%)$ & $57(66.3 \%)$ & $61(65.6 \%)$ & $69(79.3 \%)$ \\
\hline Anaphase 1/telophase I & $5(5.1 \%)$ & $4(4.2 \%)$ & $1(1.2 \%)$ & $2(2.2 \%)$ & 0 \\
\hline Metaphase II & $2(2.0 \%)$ & 0 & $3(3.5 \%)$ & $4 \quad(4.3 \%)$ & 0 \\
\hline No of oocytes & 98 & 96 & 86 & 93 & 87 \\
\hline
\end{tabular}




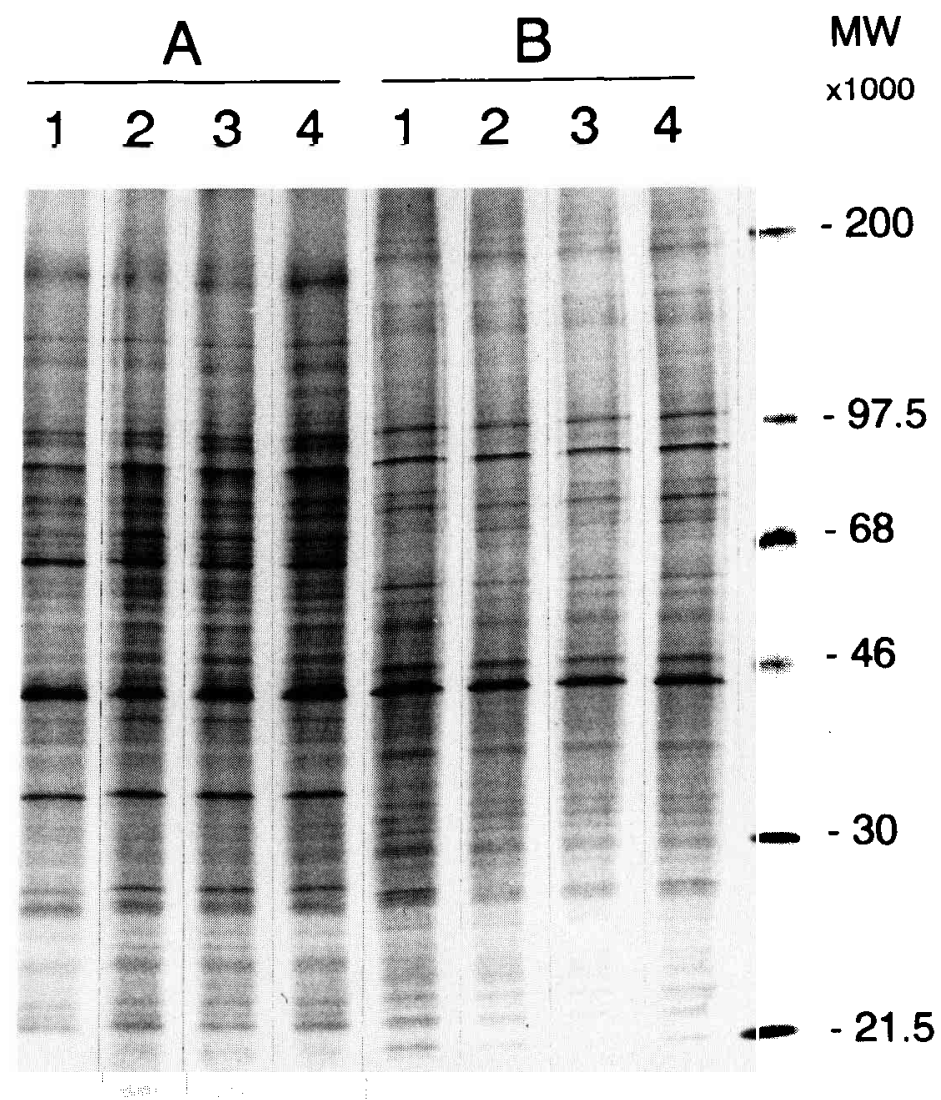

Fig 1. Autoradiogram of $\left[{ }^{35} \mathrm{~S}\right]-$ methionine labelled proteins synthesized by pig oocytes $(\mathrm{A})$ and cumulus cells (B) cultured for $30 \mathrm{~h}$ in the presence of: 1) no inhibitors; 2) $100 \mu \mathrm{M} \mathrm{H} 7$; 3) $100 \mu \mathrm{M} \mathrm{H8}$; or 4) $100 \mu \mathrm{M}$ W7. Proteins were separated by SDS gradient polyacrylamide gel electrophoresis.

PK-A, PK-C and CaM mediated processes would play during oocyte maturation. The data presented indicate that PK-A, PK-C and/or CaM have modulating rather than dominating functions and that most of the effects are mediated through cumulus cells. In a dose-dependent manner inhibition of PK-A and PK-C with $\mathrm{H} 8$ and $\mathrm{H} 7$, respectively, slightly decreased the percentage of cumulus-enclosed oocytes able to break down their nuclear membrane (GVBD); from $76 \%$ in controls to $\approx 64 \%$ or
$54 \%$ after $\mathrm{H} 8$ and $\mathrm{H} 7$ treatment, respectively. Even at very high concentrations (> $100 \mu \mathrm{M}), \mathrm{H} 8$ had no effect on the maturation of denuded oocytes. However, inhibition of protein kinases with $\mathrm{H} 7$ decreased the rate of GVBD in denuded pig oocytes in a dose-dependent manner. There were no obvious changes in either protein synthesis or phosphorylation after treatment of oocytes with $\mathrm{H} 8$ or $\mathrm{H7}$, indicating that the phosphorylation of only a small undectable proportion of oocyte proteins could be de- 


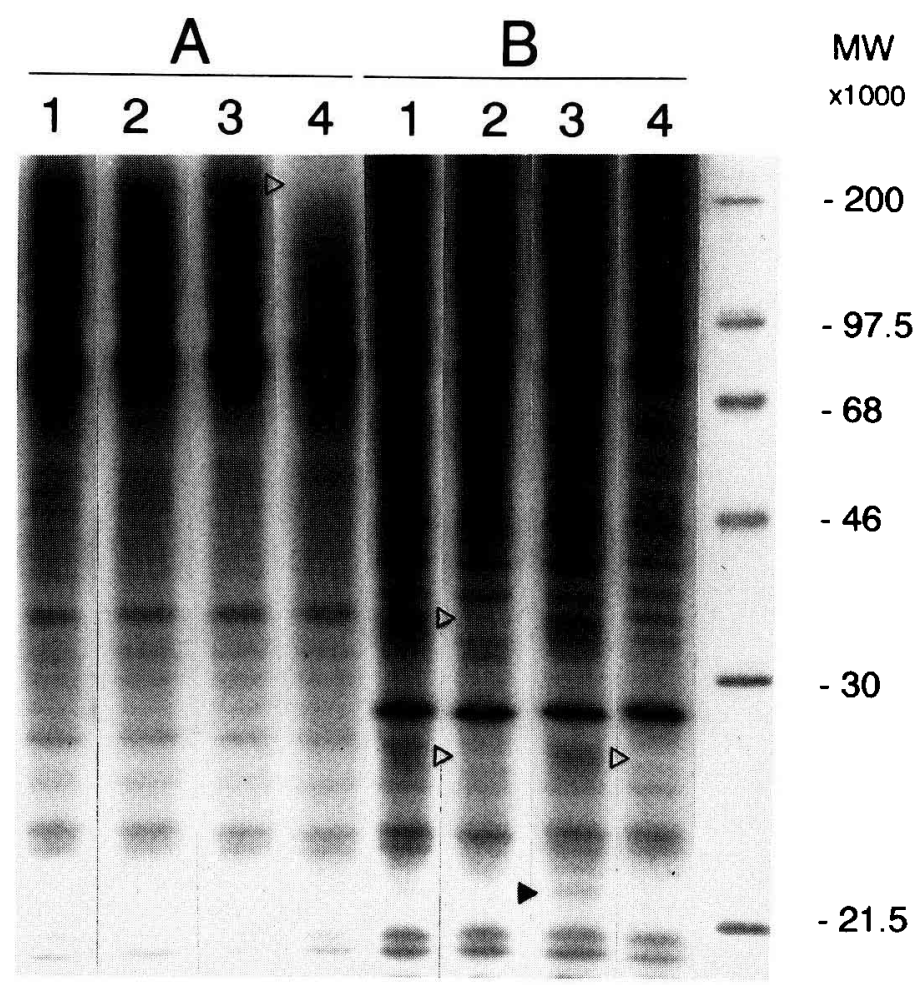

Fig 2. Autoradiogram of $\left[{ }^{32} \mathrm{P}\right]$-orthophosphate labelled proteins of pig oocytes $(\mathrm{A})$ and cumulus cells (B) cultured for $30 \mathrm{~h}$ in the presence of: 1) no inhibitors; 2) $100 \mu \mathrm{M} \mathrm{H} 7$; 3) $100 \mu \mathrm{M} \mathrm{H} 8$; or 4) $100 \mu \mathrm{M}$ W7. Proteins were separated by SDS gradient polyacrylamide gel electrophoresis. Open arrowheads indicate a decrease and filled arrowheads an increase compared to control groups.

pendent on PK-A or PK-C activity. By contrast, cumulus cell phosphorylation was markedly and selectively altered by each of the protein kinase inhibitors. Thus, $\mathrm{H} 7 \mathrm{de}-$ creased phosphorylation of $33-$ and $28-\mathrm{kDa}$ proteins whilst $\mathrm{H} 8$ increased phosphorylation in a 23-kDa protein. We interpret these results as suggesting that these agents exert a direct effect on cumulus cells, which is then reflected by an indirect effect on oocyte maturation.

The CaM antagonist W7 had no effect on pig oocyte maturation in vitro and on protein synthesis of oocytes and cumulus cells. However, phosphorylation of a 200$\mathrm{kDa}$ protein in oocytes was inhibited and that of a $28-\mathrm{kDa}$ protein in cumulus cells was decreased.

Naphthalene sulfonamides such as W7 are potent CaM antagonists with a $K_{i}$ of $\approx 40 \mu \mathrm{M}$ to inhibit $\mathrm{Ca}^{2+}-\mathrm{CaM}$ dependent enzymatic reactions in vitro and in vivo ( $\mathrm{Hi}-$ daka et al, 1978). W7 blocks GVBD in mouse oocytes completely at concentrations $>30 \mu \mathrm{M}$ (Bornslaeger et al, 1984). At $10 \mu \mathrm{M} \mathrm{W7}$ inhibits cleavage of 1 -cell 
mouse embryos by inhibiting DNA replication (Poueymirou and Schultz, 1990). Under these conditions protein synthesis is unaffected and the activation of the embryonic genome occurs at the correct time. If W7 treatment is started after completion of S-phase, it is no longer able to prevent subsequent cleavage. Therefore it seems that in the mouse the CaM antagonist W7 inhibits oocyte maturation at the G2- to $\mathrm{M}$ phase border and the first cleavage at the G1- to S-phase transition. In murine (Kaplan et al, 1982; Bornslaeger et al, 1984) and Xenopus oocytes (Cartaud et al, 1980; Wasserman and Smith, 1981) as in somatic tissues (Means et al, 1982), CaM constitutes $\approx 0.3 \%$ of total cellular proteins. Possible targets for $\mathrm{Ca}^{2+}-\mathrm{CaM}$ action during mouse and Xenopus oocyte maturation are $\mathrm{Ca}^{2+}-\mathrm{CaM}$ modulated phosphodiesterases and protein phosphatases. However, $\mathrm{Ca}^{2+-} \mathrm{CaM}$ modulated phosphodiesterases account for $<5 \%$ of the cyclic AMP hydrolysis in oocytes (Allende and Allende, 1982; Bornslager et al, 1984). Protein phosphatases play an important role during mouse and Xenopus oocyte maturation (Huchon et al, 1981; Foulkes and Maller, 1982; Rime et al, 1990). In contrast to the findings in the mouse, W7 at concentrations up to $200 \mu \mathrm{M}$ had no effect on pig oocyte maturation in vitro (table IV). $\mathrm{Ca}^{2+} \mathrm{CaM}$ mediated processes do not seem to play an important regulatory role during onset of oocyte maturation in the pig. Despite the use of high concentrations of the CaM antagonist W7, we were unable to detect any changes in the rate of GVBD and protein synthesis in oocytes. However, W7 altered the protein phosphorylation pattern in oocytes as well as in cumulus cells (fig 2). The importance of phosphorylation of the 200-kDa protein in oocytes, which is inhibited by $W 7$, for further maturation and for oocyte activation and of the $28-\mathrm{kDa}$ protein in cumulus cells for cumulus cell function remains to be established.
The isoquinoline sulfonamides $\mathrm{H} 7$ and $\mathrm{H} 8$ are derivatives of naphthalene sulfonamides but have the naphthalene ring replaced by isoquinoline (Hidaka et al, 1984, 1991). On basis of their different inhibitory constants $\left(K_{i}\right)$ for PK-A and PK-C, it is possible to differentiate between their effects on each of the 2 protein kinases. However, although they have different affinities, these agents affect both PK-A and PK-C as well as other protein kinases. $\mathrm{H} 7$ and $\mathrm{H} 8$ bind to the ATP-binding site of the affected protein kinases (Hidaka et al, 1984). PK-A and PK-C are inhibited by $\mathrm{H} 7$ or $\mathrm{H} 8$ with $K_{i}$ s of 3.0 and 1.2 or with $K_{i^{\prime}} \mathrm{s}$ of 6.0 and $15 \mu \mathrm{M}$, respectively (Hidaka et al, 1984). Since the $K_{i}$ s of $H 7$ and $H 8$ towards PK-A differ by a factor of $\approx 2$ and towards $P K-C$ by a factor of $\approx 10$ respectively, we could expect that PK-A would be inhibited by both agents (with $\mathrm{H} 8$ being slightly more powerful) and that PK-C would be inhibited almost exclusively by $\mathrm{H} 7$ in the range of concentrations used in our experiments.

Rat oocyte maturation induced by $\mathrm{GnRH}$ or $\mathrm{LH}$ in intact follicles in vitro is inhibited by $\mathrm{H} 7$ and $\mathrm{H} 8$ with $\mathrm{IC}_{50}$ 's of 20 and 80 or 20 and $100 \mu \mathrm{M}$, respectively (Dekel et al, 1990). Inhibition of pig oocyte maturation with $\mathrm{H} 7$ and $\mathrm{H} 8$ differs from the rat in the fact that in cumulus-enclosed oocytes, both agents decrease maturation rate in a dosedependent manner up to a concentration of $100 \mu \mathrm{M}$. Higher concentrations of $\mathrm{H} 7$ and $\mathrm{H} 8$ had no further inhibitory effects (tables I and II). Like the rat, $\mathrm{H} 7$ is the more powerful inhibitor of oocyte maturation in the pig. The effective concentrations of $\mathrm{H} 8$ in the rat and pig experiments are in a comparable range. However, the rat seems to be more sensitive to $\mathrm{H} 7$ than the pig. The relative potencies of the 2 agents in inhibiting $\mathrm{GnRH}$ - or $\mathrm{LH}$-induced oocyte maturation in the rat are proportional to the $K_{i}$, s of the inhibitors toward PK-C rather than toward PK-A (Dekel et al, 1990). A somehow similar dynamic 
was seen in our experiments with cumulusenclosed pig oocytes.

The results of the experiments with $\mathrm{H} 8$ seem to indicate that the normal activity of PK-A in oocytes plays only a minor role during oocyte maturation and that the kinase activity in the cumulus cells is the main modulator for the observed effects on oocyte maturation. In accordance with this is the finding that the only $\mathrm{H} 8$ induced changes in protein phosphorylation were seen in cumulus cells. The phosphorylation of a 23-kDa protein was increased. This paradoxical phenomenon, ie that a protein kinase inhibitor increases protein phosphorylation, may be explained by the fact that for example the phosphoprotein phosphatase 1 is activated by PK-A (Ingrebritsen and Cohen, 1983; Hemmings Jr et al, 1984).

It must however be recalled that the maturation of only a small proportion of cumulus-enclosed pig oocytes $(15-20 \%)$ is inhibited by blocking PK-A activity. Surprisingly, activators of PK-A activity like dbcAMP when used at high concentrations (280-1 $000 \mu \mathrm{M})$, decrease maturation of cumulus-enclosed oocytes to the same limited degree as seen after inhibition of PK-A activity (Rice and mcGaughy, 1981; Racowsky, 1983; Petr et al, 1991). The response in denuded oocytes is, however, different - with activators of PK-A decreasing maturation (Rice and McGaughey, 1981) whilst inhibitors of PK-A activity are without effect.

Cyclic AMP regulatory processes play a unique dominating role in the onset of mouse oocyte maturation (Cho et al, 1974; Wassarman et al, 1976; Bornslaeger et al, $1986 a$, b). High cyclic AMP levels prevent maturation and spontaneous maturation in vivo and in vitro is paralleled by a decline of cyclic AMP levels in the oocyte (Schultz et al, 1983; Vivarelli et al, 1983). Bornslaeger et al (1986a) were able to show that PK-A is directly involved in the cyclic
AMP-dependent meiotic arrest in mouse oocytes. In contrast to the mouse, there is no parallel decline in cyclic AMP levels during maturation in pig oocytes (Racowsky, 1985). All these findings in the pig suggest a more modulatory role of cyclic AMP and of PK-A activity during oocyte maturation compared with their more dominating role in the mouse.

$\mathrm{H} 7$ compared to $\mathrm{H} 8$ is the more powerful protein kinase inhibitor in blocking GVBD in the rat (Dekel et al, 1990) as well as in the pig (tables I and II). The relative potencies of the 2 agents correspond to their $K_{i}$ s towards PK-C rather than to PKA. From experiments in the rat we know that $\mathrm{LH}$ is able to stimulate cyclic AMP and inositol triphosphate in granulosa cells (Davies et al, 1986), and therefore most probably PK-A and PK-C. H7 inhibited the phosphorylation of 32 and $28-\mathrm{kDa}$ proteins in pig cumulus cells. These changes in cumulus cell protein phosphorylation are different from those induced by $\mathrm{H} 8$ (increased phosphorylation are different from those induced by $\mathrm{H} 8$ (increased phosphorylation at $23 \mathrm{kDa}$; fig 3) and are therefore most probably PK-C-mediated. The fact that $\mathrm{H} 7$ and $\mathrm{W} 7$ induced a similar inhibition of phosphorylation at $28 \mathrm{kDa}$ in cumulus cells indicates a role of $\mathrm{Ca}^{2+}$-mediated processes in cumulus cell action on pig oocyte maturation. Activators of $\mathrm{PK}-\mathrm{C}$, like phorbol esters, inhibit maturation of denuded mouse oocytes and of follicle-enclosed rat oocytes (Urner and SchorderetSlatkine, 1984; Aberdam and Dekel, 1985; Bornslaeger et al, 1986b; Alexandre and Mulnard, 1988). In amphibians progesterone- and phorbol ester-induced oocyte maturation is inhibited by $\mathrm{H} 7$ and $\mathrm{W} 7$ (Kwon and Lee, 1991). A > 50\% inhibition of maturation is achieved with $100 \mu \mathrm{M} \mathrm{H} 7$ or W7 for both activators.

Beside the effects on cumulus cells, $\mathrm{H} 7$ exerted direct effects on pig oocytes. However, after inhibition of $\mathrm{PK}-\mathrm{C}$ with $\mathrm{H} 7$ a 
large proportion of pig oocytes escaped the inhibitory action. Again like the situation of the cyclic AMP-dependent system, the PK-C action during pig oocyte maturation is a more modulatory system compared to more dominant role played by PK$\mathrm{C}$ during oocyte maturation in mouse, rat and amphibians. The results from our experiments in which pig oocytes were treated with both inhibitors (table III) suggest that there are no obvious more-thanadditive interactions between PK-A and PK-C activities in cumulus-enclosed pig oocytes. The observed results are not different from the expected effects, assuming simple additive interactions.

The puromycin analog 6-dimethylaminopurine (6-DMAP) totally inhibits meiotic maturation of marine invertebrate and mammalian oocytes (Neant and Guerrier, 1988a,b; Neant et al, 1989; Rime et al, 1989; Rime and Ozon, 1990; Motlik and Rimkevicova, 1990; Fulka et al, 1991; Szöllösi et al, 1991) by inhibiting protein phosphorylation. Protein synthesis is not a affected by 6-DMAP (Neant and Guerrier, 1988b; Rime et al, 1989). The target kinases for 6-DMAP are cyclic AMP and $\mathrm{Ca}^{2+-i n d e p e n d e n t ~ s e r i n e ~ a n d ~ t h r e o n i n e ~ k i-~}$ nases Neant and Guerrier, 1988b). Therefore, 6-DMAP seems to act on protein kinases not directly involved in the interaction between cumulus cells and oocyte and the known second messenger systems.

We conclude from the combined result of earlier reports and our present results that the pathways involving PK-A, PK-C and CaM play more minor and more modulatory role in pig oocytes as compared to the more dominating roles in mouse, rat and amphibians. An interaction between cumulus cells and oocyte in transferring second messengers is obvious. Cumulus cells as well as oocytes could be direct or indirect targets of the inhibitors. It remains to be established which second messen- ger molecules are generated in pig cumulus cells in response to the systemic hormonal stimuli which are then transferred to the oocyte to release meiotic arrest and initiate maturation and which oocyte factors feed back to regulate cumulus cell function. However, a major limitation of all in vitro oocyte maturation systems in assessing the interaction between cumulus cells and oocyte in the regulation of oocyte maturation is the fact that oocytes start to mature spontaneously after release from their follicles. New improved culture systems should be developed in which oocytes remain arrested in the GV stage in vitro until they are released by hormonal stimuli.

\section{ACKNOWLEDGMENT}

$T J$ was supported by a training grant from the DFG (Ju 193/1-1, Ju 193/1-2).

\section{REFERENCES}

Aberdam E, Dekel N (1985) Activators of proteinkinase $C$ stimulate meiotic maturation in rat oocytes. Biochem Biophys Res Commun $132,570-574$

Alexandre H, Mulnard J (1988) Time-lapse cinematography study of the germinal vesicle behaviour in mouse primary oocytes treated with activators of protein kinase $A$ ad $C$. Gamete Res 21, 359-365

Allende CC, Allende JE (1982) Calmodulindependent cyclic nucleotide phosphodiesterase of amphibian oocytes is inhibited in vivo. Biochem Int 5, 91-96

Bornslaeger EA, Wilde MW, Schultz RM (1984) Regulation of mouse oocyte maturation: involvernent of cyclic AMP phosphodiesterase and calmodulin. Dev Biol 105, 488-499

Bornslaeger EA, Mattei P, Schultz RM (1986a) Involvement of cAMP-dependent protein kinase and protein phosphorylation in regulation of mouse oocyte maturation. Dev Biol $114,453-462$ 
Bornslaeger EA, Poueymirou W, Schultz RM (1986b) Effects of protein kinase $C$ activators on germinal vesicle breakdown and polar body emission of mouse oocytes. Exp Cell Res 165, 507-517

Cartaud A, Ozon R, Walsh MP, Haiech J, Demaille JD (1980) Xenopus laevis oocyte calmodulin in the process of meiotic maturation. $J$ Biol Chem 255, 9404-9408

Cho WK, Sterns S, Biggers JD (1974) Inhibitory effect of dibutyryl cAMP on mouse oocyte maturation in vitro. J Exp Zool 187, 383-386

Davis JS, Weakland LU, West LA, Farese RV (1986) Luteinizing hormone stimulates the formation of inositol triphosphate and cyclic AMP in rat granulosa cells. Biochem $J 238$, 597-604

Dekel N, Beers WH (1978) Rat oocyte maturation in vitro: relief of cyclic AMP inhibition by gonadotropins. Proc Natl Acad Sci USA 75, 4369-4373

Dekel N, Galiani D, Aberdam E (1990) Regulation of rat oocyte maturation: involvement of protein kinases. In: Fertilization in Mammals (Bavister BD, Cummins J, Roldan ERS, eds) Serono Symp Norwell, MA, 17-24

Foulkes JG, Maller JL (1982) In vivo actions of protein phosphatase inhibitor-2 in Xenopus oocytes. FEBS Lett 150, 155-160

Fulka $\mathrm{J} J \mathrm{r}$, Leibfried-Rutledge ML, First NL (1991) Effect of 6-dimethylaminopurine on germinal vesicle breakdown of bovine oocytes. Mol Reprod Dev 29, 379-384

Hemmings $\mathrm{HC} J \mathrm{~J}$, Greengard $\mathrm{P}$, Lim Tung HY, Cohen P (1984) DARPP-32, a dopamineregulated neuronal phosphoprotein, is a potent inhibitor of protein phosphatase-1. Nature (Lond) 310, 503-505

Hidaka $\mathrm{H}$, Asano $\mathrm{M}$, Iwadare $\mathrm{S}$, Matsumoto I, Totsuka T, Aoki N (1978) A novel vascular relaxing agent, $\mathrm{N}$-(6-aminohexyl)-5-chloro-1naphthalenesulfonamide which affects vascular smooth muscle actomyosin. J Pharmacol Exp Ther 207, 8-15

Hidaka $\mathrm{H}$, Inagaki $\mathrm{M}$, Kawamoto $\mathrm{S}$, Sasaki $\mathrm{Y}$ (1984) Isoquinolinesulfonamides, novel and potent inhibitors of cyclic nucleotide dependent protein kinase and protein kinase $\mathrm{C}$. Biochemistry 23, 5036-5041

Hidaka H, Watanabe M, Kobayashi R (1991) Properties and use of $\mathrm{H}$-series compounds as protein kinase inhibitors. Meth Enzymol 201, 328-339

Huchon D, Ozon R, Demaille JG (1981) Protein phosphatase- 1 is involved in Xenopus oocyte maturation. Nature (Lond) 294, 358-359

Ingrebritsen TS, Cohen P (1983) Protein phosphatases: properties and role in cellular regulation. Science 221, 331-338

Kaplan G, Abreu SL, Bachvarova R (1982) rRNA accumulation and protein synthesis patterns in growing mouse oocytes. $J$ Exp Zool 220, 361-370

Kwon HB, Lee WK (1991) Involvement of protein kinase $C$ in the regulation of oocyte maturation in amphibians (Rana dybowskii). $J$ Exp Zool 257, 115-123

Laemmli UK (1969) Cleavage of structural proteins during the assembly of the head of bacteriophage T4. Nature (Lond) 227, 680-685

Magnusson C, Hillensjö T (1977) Inhibition of maturation and metabolism in rat oocytes by cyclic AMP. J Exp Zool 201, 139-147

Maller JL (1983) Interaction of steroids with the cyclic nucleotide system in amphibian oocytes. Adv Cyclic Nucleotide Res 15, 295336

Means AR, Tash JS, Chafouleas JG (1982) Physiological implications of the presence, distribution, and regulation of calmodulin in eukaryotic cells. Physiol Rev 62, 1-39

Motlik J, Rimkevicova Z (1990) Combined effects of protein synthesis and phosphorylation inhibitors on maturation of mouse oocytes in vitro. Mol Reprod Dev 27, 230-234

Neant I, Guerrier P (1988a) Meiosis reinitiation in the mollusc Patella vulgata. Regulation of MPF, CSF and chromosome condensation activity by intracellular $\mathrm{pH}$, protein synthesis and phosphorylation. Development 102, 505-516

Neant I, Guerrier P (1988b) 6-Dimethylaminopurine blocks starfish oocyte maturation by inhibiting a relevant protein kinase activity. Exp Cell Res 176, 68-79

Neant I, Charonneau M, Guerrier P (1989) A requirement for protein phosphorylation in regulating the meiotic and mitotic cell cycles in echinoderms. Dev Biol 132, 304-314

Paleos GA, Powers RD (1981) The effect of calcium on the first meiotic division of the mammalian oocyte. J Exp Zool 217, 409-416 
Petr J, Zetová L, Fulka J Jr (1991) Influence of dbcAMP on the inhibitory effect of cumulus cell factor(s). Reprod Nutr Dev 31, 135-140

Poueymirou WT, Schultz RM (1990) Regulation of mouse preimplantation development: inhibitory effect of the calmodulin antagonist W-7 on the first cleavage. Mol Reprod Dev 26, 211-216

Powers RD, Paleos GA (1982) Combined effects of calcium and dibutyryl cyclic AMP on germinal vesicle breakdown in the mouse oocyte. J Reprod Fertil 66, 1-8

Racowsky C (1983) Androgenic modulation of cyclic adenosine monophosphate (cAMP)dependent meiotic arrest. Biol Reprod 28, 774-787

Racowsky C (1985) Effects of forskolin on maintenance of meiotic arrest and stimulation of cumulus expansion, progesterone and cyclic AMP production by pig oocyte-cumulus complexes. J Reprod Fertil 74, 9-21

Rice C, McGauchey RW (1981) Effect of testosterone and dibutyryl cAMP on the spontaneous maturation of pig oocytes. J Reprod Fertil 62, 245-256

Rime H, Ozon R (1990) Protein phosphatases are involved in the in vivo activation of histone $\mathrm{H} 1$ kinase in mouse oocyte. Dev Biol $141,115-123$

Rime H, Neant I, Guerrier P, Olon R (1989) 6dimethylaminopurine (6-DMAP), a reversible inhibitor of the transition to metaphase during the first meiotic cell division of mouse oocytes. Dev Biol 133, 169-179

Sato E, Koide SS (1987) Biochemical transmitters regulating the arrest and resumption of meiosis in oocytes. Int Rev Cytol 106, 1-33

Schultz RM, Montgomery RR, Belanoff JR (1983) Regulation of mouse oocyte meiotic maturation: implication of a decrease in oocyte cAMP and protein phosphorylation in commitment to resume meiosis. Dev Biol 97, 264-273

Szöllösi MS, Debey P, Szöllösi D, Rime H, Vautier $D$ (1991) Chromatin behaviour under influence of puromycine and 6-DMAP at different stages of mouse oocyte maturation. Chromosoma 100, 339-354

Urner F, Schorderet-Slatkine S (1984) Inhibition of denuded mouse oocyte meiotic maturation by tumor promoting phorbol esters and its reversal by retinoids. Exp Cell Res 154, 600-605

Vivarelli $E$, Conti $M$, Defelici $M$, Siracusa $G$ (1983) Meiotic resumption and intracellular cAMP levels in mouse oocytes treated with compounds which act on cAMP metabolism. Cell Differ 12, 271-276

Wassarman PM, Josefowicz WJ, Letourneau GE (1976) Meiotic maturation of mouse oocytes in vitro: inhibition of maturation of specific stages of nuclear progression. $J$ Cell Sci 22, 531-545

Wasserman WJ, Smith LD (1981) Calmodulin triggers the resumption of meiosis in amphibian oocytes. J Cell Biol 89, 389-394 